\title{
SPROSTOWANIE ORZECZENIA W POLSKIM, SŁOWACKIM I CZESKIM POSTĘPOWANIU SĄDOWOADMINISTRACYJNYM
}

\section{WPROWADZENIE}

W polskim postępowaniu sądowoadministracyjnym (zarówno w pierwszej, drugiej instancji, jak i w postępowaniu międzyinstancyjnym ${ }^{1}$ ) wydawane sa orzeczenia (wyroki i postanowienia), a także zarządzenia przewodniczącego i referendarzy sądowych ${ }^{2}$. Podobne orzeczenia wydawane są w słowackim postępowaniu sądowoadministracyjnym (wyroki - $\$ 137$ s.s.p. ${ }^{3}$ oraz postanowienia - 147 s.s.p.) oraz w czeskiej regulacji (orzeczenia mają formę wyroków lub postanowień, gdy ustawa tak stanowi - $§ 53$ ust. 1 s.ř.s. $\left.{ }^{4}\right)$. Wskazane formy rozstrzygnięć moga zostać dotknięte wadą o charakterze nieistotnym, nieskutkującą koniecznością ich wyeliminowania z obrotu prawnego, czy też nieistnieniem, lecz wymagajacca rektyfikacji ${ }^{5}$. Generalnie sądy administracyjne są związane wydanym orzeczeniem (art. 144 p.p.s.a. ${ }^{6}, \S 138$ s.s.p., $§ 150$ s.s.p., por. $§ 54$ ust. 5 i $\S 55$ s.ř.s.) i nie moga w nie ingerować, poza przypadkami wynikającymi z wniesienia środka odwoławczego, uruchamiającego tok instancji. Do innych wyjątków od autoprekluzji (tj. związania sądu) należy zaliczyć dopuszczalność zastosowania jednego z trybów służaccych swoistego rodzaju „oczyszczeniu orzeczenia”, jakim jest sprostowanie uchybień i błędów w nim zawartych, przez sąd, który je wydał (z wyjątkiem, o którym mowa

1 Zob. Ziółkowska (2019): 159-330.

2 Szerzej zob. np. Piątek (2017): 44-50.

${ }^{3}$ Słowacka ustawa o postępowaniu sądowoadministracyjnym z 21 maja 2015 r. (Spravny sudny poriadok). Zauważyć należy, że na skutek nowelizacji, która zacznie obowiąywać od 1 maja 2020 r. (w wyniku ustawy 413/2019 Z. z., Ustawa [Zákon] z 26 listopada 2019 r., zmieniająca i uzupełniająca ustawę nr 180/2014 ze zm. o podmienkach výkonu volebného práva a o zmene a doplnení niektorých zákonov v znení neskorších predpisov a ktorým sa menia niektoré zákony, <https://www.slov-lex.sk/pravne-predpisy/SK/ZZ/2015/162/20200501.html>) przepis dotyczący sprostowania nie ulegnie zmianie.

${ }^{4}$ Czeska regulacja postępowania przed sądami administracyjnymi została zawarta w ustawie z 21 marca 2002 r. (Zákon soudní řád správní).

${ }^{5}$ Łac. rectificātiō - „wyprostowanie, wyjaśnienie”; por. Sondel (1997): 824. Zwrot „rektyfikacja wyroków” został wypracowany w doktrynie cywilnego prawa procesowego przez Litauera (1933: $\left.1^{*} \mathrm{n}\right)$.

6 T.jedn.: Dz. U. 2019, poz. 2325 ze zm. 
w art. $156 \S 3$ p.p.s.a.), co jest podyktowane zarówno względami celowościowymi, jak i niezbędności.

Problematyka trybów rektyfikacyjnych, w tym sprostowania orzeczenia, w postępowaniu sądowoadministracyjnym, pomimo swojej doniosłości podyktowanej względami teoretycznymi - gdyż pozostaje w ścisłym związku m.in. z kwestią związania sądu wydanym orzeczeniem czy też jego wykonaniem nie stanowi przedmiotu odrębnych opracowań naukowych, niemniej jednak jest przedmiotem licznego orzecznictwa sądowego, co pozwala uznać ją za mającą ważne znaczenie praktyczne.

Polska, Słowacja i Czechy wywodzą się z historycznie z tzw. bloku wschodniego i na drodze zmierzajacej do unormowania procedury sądowoadministracyjnej w aktualnie obowiąującym modelu wykorzystywały regulację postępowania cywilnego. Pomimo tych podobieństw różnią się sposobem ukształtowania sądownictwa administracyjnego, a także procedury sądowoadministracyjnej oraz poszczególnych jej instytucji. Celem opracowania jest próba analizy komparatystycznej trzech systemów prawnych regulujących postępowanie sądowoadministracyjne $\mathrm{w}$ wymienionych państwach. Punktem wyjścia jest wskazanie istoty i sposobu unormowania instytucji sprostowania orzeczenia wydanego przez sąd administracyjny, w szczególności przez pryzmat czterech kryteriów: zakresu podmiotowego i przedmiotowego, terminu i trybu sprostowania oraz skutków jego zastosowania. Dokonane ustalenia pozwola na wskazanie podobieństw oraz różnic badanych reżimów prawnych w zakresie analizowanej instytucji, a także sformułowanie wniosków de lege ferenda.

\section{ISTOTA SPROSTOWANIA ORZECZENIA}

Rozważania dotyczace sprostowania orzeczenia należy rozpoczać od miejsca regulacji tego trybu w systematyce aktów normatywnych analizowanych reżimów prawnych. Instytucja sprostowania została uregulowana w polskim postępowaniu sądowoadministracyjnym w przepisie art. 156 ust. 1-4 p.p.s.a. zawartym w rozdz. 10: „Orzeczenia sądowe”. Słowacki ustawodawca tryb sprostowania - oprava - zawarł w dwuzdaniowej normie prawnej § 143 s.s.p., który znajduje się w rozdz. 4 pierwszej części zatytułowanej orzeczenia. W regulacji czeskiej tryb sprostowania - oprava - został uregulowany w również w dwuzdaniowej normie $\S 54$ ust. 4 s.ř.s. ujętej w części trzeciej tytuł pierwszy ustawy. W konsekwencji należy przyjąć, iż ustawodawcy w sposób identyczny i - jak się wydaje - właściwy umieścili instytucję sprostowania wśród przepisów regulujacych orzeczenia wydawane w postępowaniu sądowoadministracyjnym. Słuszność miejsca tych przepisów w systematyce regulacji postępowań sądowoadministracyjnych wyraża się wszakże w tym, że odnoszą się one do ewentualnych jego technicznych uchybień, nieuzasadniających zmiany lub uchylenia samego orzeczenia.

Bez względu na zakres i wielość przepisów normujących tę instytucję jej cel we wskazanych postępowaniach jest tożsamy - zachowanie powagi wy- 
miaru sprawiedliwości oraz realizacja postulatu pewności obrotu prawnego. Poprawność orzeczenia, także w aspekcie braku wad nieistotnych, jest bowiem pożądana w każdym porządku prawnym, zarówno z punktu widzenia sądu wydającego orzeczenia, jak i strony będącej jego adresatem.

Istota sprostowania jako środka rektyfikacyjnego jest naprawienie orzeczenia $^{7}$ (wyroku, postanowienia - por. art. 166 p.p.s.a. oraz $§ 147$ ust. 1 i 2 s.s.p., $§ 55$ ust. 5 s.r.r.s.) lub zarządzenia (por. art. 167 p.p.s.a., art. 167 a p.p.s.a.) dotkniętego wadliwością wskazana przez ustawodawcę i nadanie mu takiego brzmienia, jakie sąd zamierzał nadać. Ma zatem służyć przywróceniu rzeczywistej woli składu orzekającego. Niemniej taka „korekta” nie może skutkować zmianą lub uchyleniem orzeczenia, które są możliwe przez zastosowanie właściwego środka odwoławczego ${ }^{8}$ zawsze na wniosek legitymowanego podmiotu, a nie przez sąd z urzędu. Sprostowanie oraz pozostałe instytucje rektyfikacyjne, czyli uzupełnienie i wyjaśnienie, nie są bowiem konkurencyjne względem siebie oraz środków odwoławczych, ale stanowią odrębne od nich działanie sądu, zarówno pod względem charakteru, jak i skutków. I choć tryby te nie wykluczają się wzajemnie (niekonkurencyjność wewnętrzna), nie mogą być stosowane zamiennie ${ }^{9}$, a stronie nie przysługuje prawo wyboru ani pomiędzy nimi, ani też między nimi a środkami odwoławczymi ${ }^{10}$ (niekonkurencyjność zewnętrzna). Nie należy przy tym a priori wykluczyć możliwości jednoczesnego poddania orzeczenia właściwemu środkowi odwoławczemu i sprostowaniu, jednakże we właściwych dla nich zakresach.

W doktrynie postępowania cywilnego wskazuje się, że czynności rektyfikacyjne polegajace na sprostowaniu orzeczenia nie sa aktami wymiaru sprawiedliwości i należałoby je raczej zaliczyć do pewnego rodzaju jurysdykcji wewnętrznej sądu, której celem jest spowodowanie jasności intencji sądu ${ }^{11}$.

Biorąc pod uwagę powyższe, należy stwierdzić, że sprostowanie jest czynnością sądu o charakterze deklaratoryjnym ${ }^{12}$, mającą moc wsteczna ${ }^{13}$, tj. od momentu wydania orzeczenia, znajdująca zastosowanie tylko do wskazanych w przepisach procesowych wad nieistotnych orzeczeń. Ich charakter uzasadnia korektę przeprowadzona przez sąd, który wydał orzeczenie, bez potrzeby angażowania sądu wyższej instancji, za czym przemawiają względy ekonomiki procesowej oraz paradygmat czasu postępowania, tak ważne w każdym reżimie prawnym.

${ }^{7}$ Instytucja sprostowania znajduje zastosowanie w stosunku do wyroków postanowień, zarządzeń, lecz nie wobec odpisów wyroków.

8 Zob. np. postanowienia NSA: z 12 sierpnia 2015 r., II FZ 491/15, Legalis nr 1333420; z 16 stycznia 2015 r., II OZ 1120/14, Legalis nr 1181263; tak też wyrok NSS z 21 lutego 2007, čj. 4 Ans 3/2006-123, Sb. NSS 1177/2007, <https://sbirka.nssoud.cz>; Rosengarten (1971): 873. Istota związania wyrokiem wyraża się w niedopuszczalności zmiany treści rozstrzygnięcia - por. Kunicki (2010): 182.

9 Por. Adamiak (1988): 8.

10 Zadrożniak (2008): 1139; Gapska (2009): 194-195.

11 Lubiński (2016): 800 i podana tam literatura.

12 Por. Lubiński (2016): 800; Piasecki (1987): 373; Woś (2015): 486.

13 Litauer (1933): 6; Piasecki (1961): 11. 


\section{ZAKRES PODMIOTOWY SPROSTOWANIA}

W analizowanych procedurach środek rektyfikacyjny w postaci sprostowania nie ma charakteru dewolutywnego, nie uruchamia toku kontroli instancyjnej, gdyż „naprawienie” orzeczenia w tym trybie nie wymaga zaangażowania sądu wyższej instancji. W polskim dwuinstancyjnym postępowaniu sądowoadministracyjnym sądem właściwym do zastosowania trybu sprostowania jest zasadniczo sąd, który wydał orzeczenie. Niemniej także Naczelny Sąd Administracyjny może z urzędu sprostować wyrok pierwszej instancji, jeżeli sprawa toczy się przed tym sądem (por. art. $156 \S 3$ p.p.s.a.) ${ }^{14}$, a sąd ten oddala skargę kasacyjna, pozostawiając w mocy wyrok pierwszej instancji dotknięty wadami nieistotnymi uzasadniajacymi podjęcie czynności rektyfikacyjnych. Kompetencji takiej nie ma wojewódzki sąd administracyjny w stosunku do orzeczeń sądu drugoinstancyjnego.

Sprostowanie może zostać zainicjowane przez sąd ex officio, na co wskazuje przepis art. $156 \S 1$ p.p.s.a. Nadto w orzecznictwie sądowym ${ }^{15}$ oraz w doktrynie ${ }^{16}$ wskazuje się na dopuszczalność wniesienia wniosku o sprostowanie orzeczenia przez stronę i uczestnika na prawach strony, co potwierdza treść przepisu art. 159 p.p.s.a., a także możliwość wniesienia zażalenia na postanowienie o odmowie sprostowania wynikająca z treści przepisu art. $194 \S 1$ pkt 5 p.p.s.a.

W słowackim dwuinstancyjnym postępowaniu sądowoadministracyjnym sprostowania orzeczenia dokonuje sąd z urzędu lub na wniosek strony ${ }^{17}$ albo innych uczestników postępowania, w tym prokuratora ${ }^{18}$. Z kolei w czeskim postępowaniu sądowoadministracyjnym, zasadniczo jednoinstancyjnym ${ }^{19}$, właściwy do sprostowania orzeczenia jest przewodniczacy izby (předseda senátupor. $§ 16$ ust. 1 s.ř.s.) podejmujący czynności rektyfikacyjne w omawianym zakresie z urzędu, ale także na wniosek ( 54 ust. 4 s.ř.s.)

Dopuszczalność sprostowania orzeczenia zarówo z inicjatywy sądu, jak i na wniosek pozostaje w związku z czynnościa jego wykonania, rozumiana jako realizacja jego treści. Niemniej nie tylko dla sądu administracyjnego, lecz także dla adresata orzeczenia istotne znaczenie ma poprawność orzeczenia (czyli w tym przypadku brak wad nieistotnych). W doktrynie bowiem podkreśla się, że wykonaniu podlega „każdorazowo treść wyroku dekodowana przede wszystkim z jego sentencji, a uzupełniająco - także z uzasadnienia" ${ }^{20}$. Brak mankamentów w orzeczeniu z jednej strony sprzyja zatem budowaniu autorytetu sądu, a z drugiej - pozwala na wykonanie rzeczywistej woli sądu w nim wyrażonej. Słusznie zatem instytucja sprostowania orzeczenia może zostać uruchomiona w dwojaki sposób.

${ }^{14}$ Por. wyrok NSA z 2 października 2019 r., II FSK 1142/19, Legalis nr 2247309.

${ }_{15}$ Por. postanowienia NSA: z 16 maja 2018 r., II FSK 300/16, Legalis nr 1769696; z 11 maja 2017 r., II OSK 1869/15, Legalis nr 1626450; z 10 sierpnia 2011 r., I OSK 922/11, Legalis nr 636514.

${ }_{16}$ Tarno (2010): 374.

${ }^{17}$ Hanzelová, Rumana, Šingliarová (2016): 240; Dauter (2018): 511.

18 Baricová, Duditš (2018): 732.

${ }^{19}$ Ziółkowska (2019): 366-367 i podana tam literatura.

${ }^{20}$ Piątek (2017): 57. 


\section{ZAKRES PRZEDMIOTOWY SPROSTOWANIA}

Zakres przedmiotowy zastosowania środka rektyfikacyjnego w postaci sprostowania w polskim postępowaniu sądowoadministracyjnym jest zbieżny z tym, który ustawodawca przewidział w postępowaniu cywilnym w art. 350 $\S 1$ k.p.c. ${ }^{21}$ Jak bowiem wynika z treści art. $156 \S 1$ p.p.s.a. sąd może sprostować w wyroku niedokładności, błędy pisarskie albo rachunkowe lub inne oczywiste omyłki. W słowackim postępowaniu sądowoadministracyjnym w omawianym trybie można usunać błędy pisarskie i rachunkowe, a także inne oczywiste niedokładności - 143 zd. 1 s.s.p. („chyby v písaní a počítaní, ako aj iné zrejmé nesprávnosti”). Podobne brzmienie ma $§ 54$ ust. 4 zd. 1 s.řs.s. („chyby v psaní a počtech, jakož i jiné zjevné nesprávnosti”) pozwalający na sprostowanie wyroku, w którym występują błędy pisarskie i rachunkowe, a także inne oczywiste niedokładności. W pierwszej kolejności podkreślenia wymaga, że w rozważanych systemach zostały ustawowo określone granice sprostowania orzeczenia $\mathrm{w}$ postępowaniu sądowoadministracyjnym. Ponadto dokonujacc interpretacji literalnej wskazanych przepisów, należy zauważyć, że w procedurze słowackiej i czeskiej ustawodawcy nie wskazali „niedokładności” jako odrębnej przyczyny sprostowania. Wydaje się jednak, że usterka literowa, rachunkowa czy inne oczywiste niedokładności mieszczą się w zbiorczej kategorii „niedokładności”. Podkreślenia także wymaga, że użyte przez ustawodawców zwroty „inne oczywiste omyłki”, „inne oczywiste niedokładności” mogą w praktyce orzeczniczej skutkować tendencją do ich rozszerzającej wykładni, która ma służyć znalezieniu rozwiązania w przypadkach zaistnienia mankamentów w orzeczeniu.

Istotą sprostowania $\mathrm{w}$ analizowanych postępowaniach sądowoadministracyjnych jest wyłącznie skorygowanie oczywistych błędów, o raczej „technicznym charakterze" (błędy ortograficzne, interpunkcyjne, transkrypcje, błędy liczenia, nieczytelność tekstu itp.). Ponadto granicę przedmiotową sprostowania w powyższych postępowaniach sądowoadministracyjnych stanowi oczywistość usterki, przez którą należy rozumieć natychmiastowość ich rozpoznawalności, a także jednoznaczność wynikania z treści orzeczenia ${ }^{22}$. Nadto powinny one mieć charakter pewny, niebudzący wątpliwości, bezsporny ${ }^{23}$. A contrario należy przyjąć, że omyłka pozbawiona jest przymiotu oczywistości, jeżeli jej stwierdzenie wymaga głębszej analizy akt postępowania ${ }^{24}$. Wydaje się przy tym konieczne podkreślenie, iż oczywistość omyłki czy niedokładność orzeczenia winna być definiowana w okolicznościach danej sprawy, a casu ad casum, a nie poprzez nadawanie im uniwersalnego znaczenia.

${ }^{21}$ Kodeks postępowania cywilnego z 17 listopada 1964 r., t.jedn.: Dz. U. 2019, poz. 1460 ze zm. (art. 350 § 1: „Sąd może z urzędu sprostować w wyroku niedokładności, błędy pisarskie albo rachunkowe lub inne oczywiste omyłki”).

22 Wyrok NSA z 2 października 2019 r., II FSK 1142/19, Legalis nr 2247309.

23 Por. postanowienie NSA z 17 maja 2019 r., II FSK 1512/17, Legalis nr 1919983.

24 Zob. np. wyrok SN z 24 lipca 2002 r., I CKN 886/00, Legalis nr 59272. 
Wada lub wady orzeczenia ${ }^{25}$ mają być widoczne i łatwo rozpoznawalne dla wszystkich, tzn. dla sądu, który wydał wyrok, sądu drugoinstancyjnego, jak również dla strony, w szczególności przez porównanie „sentencji wyroku z jego uzasadnieniem i ewentualnie z innych kontekstów"26. Jak jednak podkreśla się w czeskim orzecznictwie sądowym, kwestię „oczywistego błędu” należy zawsze oceniać z perspektywy adresata orzeczenia, a nie sądu ${ }^{27}$.

Zakresem sprostowania może zostać objęta każda część orzeczenia, stąd może to być wadliwość:

1) zawarta $\mathrm{w}$ jego komparycji ${ }^{28}$ (np. niewłaściwe, niedokładne określenie sadu $^{29}$ lub jego siedziby ${ }^{30}$ ), data wydania wyroku ${ }^{31}$;

2) występująca w sentencji orzeczenia, np. mylnie opisanie słownie należnych skarżącemu od organu kosztów postępowania kasacyjnego ${ }^{32}$;

3) uzasadnienia orzeczenia ${ }^{33}$. W tym zakresie możliwe są dwie sytuacje: po pierwsze (pierwotne sprostowanie) - sprostowaniu moga podlegać niedokładności, błędy pisarskie i rachunkowe czy inne oczywiste omyłki, które tkwia jedynie w uzasadnieniu, przy czym ich usunięcie nie może prowadzić do zmiany mylnych ustaleń faktycznych; po drugie (wtórne sprostowanie) - na skutek sprostowania sentencji, sprostowaniu może podlegać uzasadnienie.

Również w słowackim i czeskim postępowaniu przedmiotem sprostowania moga być błędy literowe czy usterki techniczne każdej część wyroku, w tym m.in. nagłówek, data i miejsce wydania wyroku, sygnatura, uzasadnienie, pouczenie $^{34}$.

O dopuszczalności sprostowania decyduje wpływ omyłki na treść orzeczenia sądu ${ }^{35}$. Przytoczone wyżej przepisy wskazuja na następujące przyczyny sprostowania (oczywiste): niedokładność, błąd pisarski, błąd rachunkowy oraz inne oczywiste omyłki (niedokładności).

${ }^{25}$ Por. Hanzelová, Šingliarová (2016): 240.

${ }^{26}$ Wyrok NS ČR sp. zn. 28 Cdo 2061/2010, z 12 stycznia 2011, 4 Ads 139/2011-400; wyrok NS (Sądu Najwyższego - Nejvyššího soudu ČSSR) z 27 września 1968 r., sp. zn. 2 Cz 57/1968, publikowany w zbiorze wyroków i opinii pod nr 37/1969, Nález Trybunału Konstytucyjnego (Ústavního soudu) sp. zn. II. ÚS 1456/11 z 10 kwietnia 2012 r., N 75/65 Sb NU 51, <http://nalus. usoud.cz>; wyrok NS (Nejvyššího soudu), opublikowane pod numerem R 37/1969; postanowienie NS z 20 kwietnia 2000 r., 20 Cdo 1238/99, <www.nsoud.cz>.

${ }^{27}$ Por. Nález Trybunału Konstytucyjnego II. ÚS 1456/11 z 10 kwietnia 2012 r., N 75/65 Sb NU 51, Nález Trybunału Konstytucyjnego II. ÚS 1456/11 z 10 kwietnia 2012 r., N 75/65 Sb NU 51, <http://nalus.usoud.cz>; Kocourek (2019): 455.

${ }^{28}$ Hanzelová, Šingliarová (2016): 240.

${ }^{29}$ Postanowienie NSA z 25 maja 2011 r., I OZ 369/11, Legalis nr 639877.

${ }^{30}$ Postanowienie NSA z 20 kwietnia 2012 r., I OSK 1821/11, Legalis nr 1106853.

${ }^{31}$ Postanowienie Sądu Okręgowego w Bańskiej Bystrzycy z 12 marca 2018 r., 28Sa/5/2017, $<$ https://www.epi.sk>.

${ }^{32}$ Hanzelová, Šingliarová (2016): 240.

${ }^{33}$ Por. postanowienie WSA w Gdańsku z 20 lipca 2017 r., I SA/Gd 213/17, Legalis nr 1644607; postanowienie NSA z 17 maja 2012 r., I OSK 2196/11, Legalis nr 1107555; Hanzelová, Šingliarová (2016): 240.

${ }^{34}$ Baricová, Duditš (2018): 731.

${ }^{35}$ Por. postanowienie NSA z 22 grudnia 2004 r., OZ 887/04, Legalis nr 93780. 
W doktrynie polskiego postępowania cywilnego ${ }^{36}$ wskazuje się, że „niedokładność" nadająca się do usunięcia w trybie sprostowania odnosi się do błędnego oznaczenia w wyroku przedmiotu zaskarżenia ${ }^{37}$ albo niedokładności w zakresie oznaczenia stron (np. pominięcie litery w nazwisku strony), błędu $\mathrm{w}$ imieniu pełnomocnika strony ${ }^{38}$.

„Błąd pisarski”, czyli związany z pisaniem (odręcznie czy elektronicznie), to „widoczne, wbrew zamierzeniom sądu niewłaściwe użycie wyrazu, widoczna mylna pisownia, błąd gramatyczny albo niezamierzone opuszczenie jednego lub więcej wyrazu”39, albo „wstawienie” niepasującego słowa. Moga to być nadto błędy stylistyczne i fleksyjne. Pomyłka taka, występująca w sentencji lub uzasadnieniu, powinna być widoczna na pierwszy rzut oka. Błędem takim może być usterka literowa w słowie „sąd” (lub soud $\left.{ }^{40}\right)$, niezamierzone zdublowanie wyrazu lub całych zdań.

„Błąd rachunkowy” z kolei to „błąd wynikajacy z niewłaściwego przeprowadzenia badań arytmetycznych, a w szczególności błędne zsumowanie lub odjęcie poszczególnych pozycji” ${ }^{41}$. Jest to zatem błąd matematyczny.

„Inne oczywiste omyłki” to omyłki stojące na równi z błędami pisarskimi lub rachunkowymi, polegające na tym, że wyrażono coś, co jest widocznie niezgodne z myślą wyrażoną niedwuznacznie w wyroku, a zostało wypowiedziane tylko przez przeoczenie, niewłaściwy dobór słowa itp." ${ }^{42}$ Zwrot ten ma szerszy zakres, jednakże jego charakter zbliżony jest do pojęć wymienionych wcześniej. Powinno być jednak rozumiany ściśle, w sposób zawężający. Wykładnia taka ma chronić strony przed bezzasadnym korzystaniem z możliwości sprostowania" "33. Za inną oczywistą omyłkę należy uznać przykładowo błąd interpunkcyjny, który zmienia sens wypowiedzi zawartej w orzeczeniu, lub wadliwe nazwanie orzeczenia ${ }^{44}$.

Podobnie przyjmuje się w słowackim postępowaniu sądowadministracyj$n^{n} m^{45}$. Inne oczywiste omyłki mają być podobnego rodzaju do błędów literowych czy rachunkowych. W czeskim postępowaniu zwrot „zjevná nesprávnost”

36 Por. Jakubecki (2011): 1095.

${ }^{37}$ W komparycji wyroku wskazano, że skarga wniesiona została na bezczynność organu, podczas gdy z uzasadnienia wyroku oraz z treści samej skargi wynikało, iż obejmowała ona także kwestię przewlekłości - postanowienie NSA z 15 marca 2018 r., I FSK 170/17, Legalis nr 1730607.

38 Postanowienie WSA w Warszawie z 22 listopada 2011 r., V SA/Wa 271/11, Legalis nr 438631.

${ }^{39}$ Postanowienie NSA z 21 listopada 2017 r., II GSK 2413/17, Legalis nr 1748148, a także z 2 września 2016 r., II FZ 448/16, Legalis nr 1505615; wyrok NSA z 23 kwietnia 2001 r., II SA 863/00, Lex nr 75522 .

40 Postanowienie NSS (Nejvyšší správní soud) z 20 kwietnia 2015 r., 7 As 41/2015-30, <http:// www.nssoud.cz>.

${ }^{41}$ Por. postanowienie NSA z 22 grudnia 2004 r., OZ 887/04, Lex nr 837885.

${ }^{42}$ Postanowienie WSA w Warszawie z 28 sierpnia 2015 r., V SA/Wa 881/15, Legalis nr 1366820, tak też Piasecki (1961): 9.

43 Postanowienie NSA z 1 lutego 2011 r., I OZ 60/11, Legalis nr 617135.

44 Szustakiewicz (2016): 278.

45 Wyrok Trybunału Konstytucyjnego Republiki Słowackiej (Ústavného súdu SR) z 24 lipca 2014 r., II. ÚS 576 / 2013-30, <https:/www.najpravo.sk/obchodne-pravo/judikatura/obcianske-procesne-pravo/rozhodnutie/rozsudok/oprava-inej-zrejmej-nespravnosti.html>. 
(„oczywiste pomyłki”) jest stosunkowo nieostrym zwrotem, którego zakres należy zawsze ustalać w odniesieniu do okoliczności faktycznych i prawnych.

Orzecznictwo sądowe wskazuje na przykłady uchybień usuwalnych w trybie sprostowania, należących do kategorii „innych oczywistych omyłek”, którymi mogą być błędne oznaczenie:

1) sprawy (znaku, sygnatury);

2) nazwy organu, który wydał zaskarżony akt lub podjął zaskarżoną czynnośćc ${ }^{46}$

3) adresu strony ${ }^{47}$;

4) numeru jednostki redakcyjnej aktu prawnego ${ }^{48}$;

5) formy orzeczenia ${ }^{49}$.

Za przekroczenie podmiotowej dopuszczalności sprostowania należy uznać sytuacje, w których na skutek zastosowania tego trybu następuje zmiana podmiotowa, w wyniku której stroną staje się osoba niemająca takiego statusu. Biorac pod uwagę przedmiotowy aspekt dopuszczalności sprostowania, należy przyjąć, że zakresem oczywistej omyłki nie należy obejmować przeoczeń, których dopuścił się sąd przy rozstrzygnięciu sprawy, jak również niezgodności sentencji z następnie sporządzonym uzasadnieniem ${ }^{50}$. Ponadto przedmiotem sprostowania nie może być data wniesienia skargi ${ }^{51}$, przeoczenie w sentencji orzeczenia jednego z zaskarżonych aktów lub pominięcie rozstrzygnięcia w kwestii kosztów postępowania ${ }^{52}$ albo niektórych roszczeń strony skarżącej ${ }^{53}$. Podobnie za niedopuszczalną w trybie sprostowania należy uznać zmianę treści uzasadnienia wyroku przez dopisanie niedokończonego zdania ${ }^{54}$. Niedopuszczalne jest nadto żądanie w drodze sprostowania zawarcie w uzasadnieniu wyroku akceptacji poglądu prezentowanego przez skarżącego odnośnie do jego legitymacji do domagania się stwierdzenia nieważności decyzji ${ }^{55}$ lub też takie sprostowanie części uzasadnienia, które pozostawałoby w sprzeczności z sentencją orzeczenia ${ }^{56}$. Sprostowanie nie jest dopuszczalne w przypadku błędu we wnioskowaniu lub stosowaniu prawa ${ }^{57}$. Nadto przedmiotem sprostowania nie może stać się „mylne ustalenie faktu, chociażby zostało ono spowodowane przeoczeniem"58.

${ }^{46}$ Postanowienie NSA z 2 października 2012 r., II OSK 631/12, Legalis nr 594393; postanowienie NSA z 24 stycznia 2018 r., I FSK 1677/16, Legalis nr 1735491.

${ }_{47}$ Postanowienie SN (Najvyšší súd SR), 7Sžsk/131/2018 z 18 września 2019 r. <https://www. nsud.sk>.

48 Postanowienie NSA z 2 marca 2016 r., I FPS 6/15, Legalis nr 1426131.

49 Postanowienie NSA z 9 października 2012 r., I OSK 1890/12, Legalis nr 1109603.

${ }^{50}$ Postanowienie WSA w Łodzi z 4 sierpnia 2016 r., III SA/Łd 56/16, Legalis nr 1535821.

51 Postanowienie NSA z 13 stycznia 2015 r., II OZ 1401/14, Legalis nr 1181013.

52 Postanowienia NSA: z 12 września 2013 r., II OSK 499/12, Legalis nr 914477; z 4 stycznia 2008 r., I OSK 1545/06, Legalis nr 140286.

53 Postanowienie NSA z 22 marca 2012 r., I FSK 495/10, Legalis nr 480749.

54 Postanowienie WSA w Krakowie z 9 stycznia 2012 r., II SA/Kr 758/11, Legalis nr 461449.

55 Postanowienie NSA z 10 września 2013 r., II GZ 488/13, Legalis nr 914529.

56 Kocourek (2019): 455-456.

57 Piasecki (1961): 10.

58 Postanowienie NSA z 24 lipca 2013 r., I OZ 597/13, Legalis nr 915506. 
Rozważając problem zakresu instytucji proceduralnej sprostowania, nie można pominać kwestii źródeł powstania usterek i nieścisłości orzeczenia. Należy wszakże uwzględnić nie tylko zwykłe przeoczenie czy nieuwagę sędziego, ale także fakt, że system przygotowywania orzeczeń w formie elektronicznej jest obecnie notorycznym faktem i w związku z tym za powszechne należy uznać ogólnie znane błędy, które występują podczas pracy z technologią komputerowa, np. przy edytorach tekstu z automatyczną korektą ${ }^{59}$.

W orzecznictwie sądowym sądów cywilnych ${ }^{60}$ brak jest jednolitości poglądów co do pochodzenia uchybień, tzn. czy omawiana instytucja znajduje zastosowanie wyłącznie w przypadku omyłek sądu czy także w odniesieniu do omyłek strony. W starszej doktrynie podkreśla się jednak, że źródło omyłek nie ma znaczenia $^{61}$ albo że sprostowanie znajduje zastosowanie tylko do omyłek sądu ${ }^{62}$. Podobne rozbieżności występują w postępowaniu sądowoadministracyjnym, w którym pojawiają się poglądy, zgodnie z którymi sprostowaniu może podlegać tylko oczywista pomyłka sądu ${ }^{63}$, jak i takie, które dopuszczają sprostowanie każdej omyłki bez względu na sposób powstania, także omyłkę strony ${ }^{64}$. W doktrynie słowackiej podkreśla się z kolei, że zasadniczo instytucja sprostowania służy naprawieniu błędów sądu, a nie naprawieniu wad, których dopuściła się strona wnosząca skargę do sądu ${ }^{65}$. Ma to być omyłka powstała poniekąd „mechanicznie” przez nieuwagę sędziego ${ }^{66}$. Z kolei w orzecznictwie czeskim wskazuje się, że kwestię „oczywistego błędu” należy zawsze oceniać z punktu widzenia strony, w której sprawie decyzja jest skierowana, a nie do sądu ${ }^{67}$.

Zakresem przedmiotowym sprostowania w analizowanych systemach prawnych zostały objęte podobne wady nieistotne. W trybie tym jednolicie niedopuszczalne jest naprawienie mankamentów orzeczenia polegających na błędach we wnioskowaniu, subsumcji czy stosowaniu prawa.

\section{TERMIN I FORMA SPROSTOWANIA}

Zastosowanie instytucji sprostowania nie jest ograniczone terminem, bez względu na to, czy sąd dokonuje sprostowania z urzędu czy na wniosek ${ }^{68}$.

${ }_{59}$ Por. Nález Trybunału Konstytucyjnego (Ústavního soudu) z 22 kwietnia 2014 r., II. ÚS 2678/13,II. ÚS 2678/13, <https://iudictum.cz>.

${ }^{60}$ Zob. np. wyrok SN z 8 czerwca 1977 r., IV PRN 4/77, Legalis nr 20133; postanowienie SN z 30 lipca 1996 r., I CRN 96/96, niepubl.; wyrok SN z 3 września 2010 r., I PK 67/10, Legalis nr 398013.

${ }^{61}$ Litauer (1933): 5.

${ }^{62}$ Piasecki (1961): 10; zob. też Szymanowski (2018): 83.

${ }^{63}$ Woś (2015): 307.

${ }^{64}$ Jagielska et al. (2019): 746; Dauter (2018): 512.

${ }^{65}$ Baricová, Duditš (2018): 731.

${ }^{66}$ Litauer (1933): 6.

${ }^{67}$ Por. Nález Trybunału Konstytucyjnego II. ÚS 1456/11 z 10 kwietnia 2012 r., N 75/65 Sb NU 51, <http://nalus.usoud.cz>.

${ }^{68}$ Wniosek o sprostowanie nie jest objęty obowiąziem uiszczenia wpisu, w przeciwieństwie do zażalenia na sprostowanie lub odmowę sprostowania. 
W konsekwencji należy przyjąć, że może być dokonane w każdym czasie również po uprawomocnieniu się orzeczenia. Podobnie w postępowaniu słowackim i czeskim sprostowanie nie zostało ograniczone terminem (por. § 143 s.s.p., $\S 54$ ust. 4 s.ř.s.). Również w tych regulacjach prawnych sprostowanie może zostać przeprowadzone $\mathrm{w}$ dowolnym momencie, nawet po tym, gdy wyrok stanie się prawomocny ${ }^{69}$.

W polskim postępowaniu sądowoadministracyjnym o sprostowaniu rozstrzyga sąd w tym samym składzie, w którym wydał orzeczenie stanowiące przedmiot tej instytucji ${ }^{70}$. Postanowienie o sprostowaniu lub odmowie sprostowania sąd (zarówno pierwszej instancji, jak i NSA) może wydać na posiedzeniu niejawnym (art. $156 \S 2$ p.p.s.a.) jednoosobowo (por. art. $16 \S 2$ p.p.s.a.). Na postanowienia te przysługuje środek odwoławczy w postaci zażalenia, $u t$ supra. Wymaga ono uzasadnienia z urzędu i doręczenia stronom (art. 163 p.p.s.a.). Z kolei na postanowienia o sprostowaniu postanowienia referendarza sądowego przysługuje sprzeciw (por. art. $156 \S 1$ p.p.s.a. w zw. z art. 194 $\S 1$ pkt 5 p.p.s.a.). Dopuszczalność zażalenia (sprzeciwu) należy oceniać pozytywnie, gdyż daje ono stronie gwarancję ochrony przed przekroczeniem granic sprostowania $^{71}$. Postanowienie o sprostowaniu wydane przez NSA nie podlega zaskarżeniu i jest prawomocne. Podkreślenia przy tym wymaga, że NSA może dokonać sprostowania wyroku wojewódzkiego sądu administracyjnego w postanowieniu stanowiącym element wyroku. Może nadto dokonać sprostowania niezaskarżonej części wyroku ${ }^{72}$, co ma sprzyjać z jednej strony zasadzie pewności obrotu prawnego, a z drugiej - odpowiadać względom ekonomiki procesowej.

W związku z postępująca informatyzacją polskiego postępowania sądowoadministracyjnego wyrok ${ }^{73}$ może zostać utrwalony w systemie teleinformatycznym sądu, o czym mowa w art. $137 \S 5$ p.p.s.a. W takich przypadkach wzmianka o sprostowaniu ma formę dokumentu elektronicznego opatrzonego kwalifikowanym podpisem elektronicznym (art. $156 \S 2$ a p.p.s.a.). Wzmianka o sprostowaniu stanowi oddzielny dokument elektroniczny w aktach sprawy sądowoadministracyjnej ${ }^{74}$. Jeżeli bowiem akta sądowe są prowadzone w wersji elektronicznej, to wyrok i jego sprostowanie stanowią część tych akt.

W słowackim postępowaniu, jeżeli sąd stwierdzi przesłanki zastosowania sprostowania, to bez przeprowadzenia rozprawy, na posiedzeniu niejawnym wydaje postanowienie $\mathrm{w}$ sprawie sprostowania ${ }^{75}$. Treść tego postanowienia musi być jasna oraz czytelna i musi z niej wynikać, która część wyroku została sprostowana. W przypadku wniosku sąd wyda „postanowienie napraw-

${ }^{69}$ Baricová, Duditš, (2018): 731.

${ }^{70}$ Hanzelová, Šingliarová (2016): 240.

${ }^{71}$ Por. Adamiak (1988): 10.

${ }_{72}$ Zob. postanowienie NSA z 29 grudnia 2005 r., II FSK 234/05, Legalis nr 2221883.

${ }^{73}$ Warto podkreślić, że zarządzenie przewodniczącego, jak również zarządzenia i postanowienia referendarza, do których stosuje się przepis o sprostowaniu, także mogą mieć formę elektroniczną.

${ }^{74}$ Jagielska et al. (2019): 748.

${ }^{75}$ Baricová, Duditš (2018): 731. 
cze" (opravne uznesenie) w odniesieniu do złożonego wniosku (w szczególności może w całości lub w części odrzucić propozycję sprostowania). Na postanowienie o sprostowaniu (z wyjątkiem uzasadnienia) i o odmowie uwzględnienia wniosku o sprostowanie przysługuje skarga kasacyjna ${ }^{76}$. Sąd dokonujący sprostowania doręcza postanowienie o sprostowaniu do rak strony oraz innych uczestników postępowania, o których mowa w $§ 142$ ust. 1 s.s.p.

W świetle czeskiej regulacji postępowania sądowoadministracyjnego „postanowienie naprawcze" jest wydawane tylko wówczas, gdy sprostowanie dotyczy treści sentencji, jeżeli korekta dotyczy tylko nagłówka, imienia przewodniczącego, przedstawiciela lub zastępcy procesowego strony, wówczas nie ma takiej potrzeby ${ }^{77}$. W takich bowiem sytuacjach dokonuje się korekty w sposób nieformalny, bezpośrednio na oryginalne orzeczenia i zwróconych odpisach (stejnopisech) orzeczenia ${ }^{78}$. Wydanie postanowienia w związku z zastosowaniem instytucji sprostowania stanowi czynność ponadstandardowa (procesní nadstandard), wyższą formę sprostowania. Sąd wydaje postanowienie także wówczas, gdy odmawia sprostowania na wniosek strony. Powyższe postanowienia mogą stanowić przedmiot skargi kasacyjnej ${ }^{79}$.

\section{SKUTKI SPROSTOWANIA}

Sprostowanie orzeczenia ma powodować naprawienie oczywistych wad nieistotnych, nie może zatem powodować ani zmian merytorycznych, ani zmian podmiotowych. W tym kontekście podkreślenia wymaga konieczność odróżnienia na przykład niewłaściwego oznaczenia strony od niewłaściwego oznaczenia zakresu podmiotowego, który nie podlega reżimowi instytucji sprostowania. Jak podkreślono, sprostowanie orzeczenia nie może skutkować merytoryczna zmianą zawartego w nim rozstrzygnięcia. Instytucja ta bowiem nie służy zmianie orzeczenia co do istoty sprawy ${ }^{80}$. Przekroczenie granic sprostowania przybierające postać dokonania zmian w wyroku może stanowić w polskim postępowaniu sądowoadministracyjnym pozytywną przesłankę do stwierdzenia nieważności postępowania, gdy dla rozstrzygnięcia sprawy wymagana jest rozprawa lub wznowienia postępowania sądowoadministracyjnego, gdy sprawa powinna być rozstrzygnięta w drodze wyroku (por. art. $183 \S 2$ ust. 5 p.p.s.a. i art. 271 ust. 2 p.p.s.a.).

W polskiej procedurze sądowoadministracyjnej wniosek o sprostowanie orzeczenia nie ma wpływu na bieg terminu do wniesienia środka zaskarżenia (art. 159 p.p.s.a.), co wyklucza możliwość skutecznego wniesienia wnio-

76 Baricová, Duditš (2018): 732; Potěšil, Šimiček et al. (2014): 479.

77 Wyrok NSS z 30 lipca 2015 r., č. j. 4 As 128/2015-29, <http://www.nssoud.cz>; Kocourek (2019): 456.

78 Wyrok NSS z 18 stycznia 2017 r., 3 As 238/2016-27, <https://iudictum.cz>; postanowienie NSS z 14 marca 2018 r., 7 As 56/2018-12, <https://iudictum.cz>; Kocourek (2019): 456.

${ }^{79}$ Kocourek (2019): 456.

80 Por. Drápal, Bureš et al. (2009): 1119. 
sku o przywrócenie terminu do złożenia środka odwoławczego z powodu złożenia wniosku o rektyfikację orzeczenia. Z kolei w słowackim postępowaniu sądowoadministracyjnym generalnie skargę kasacyjną należy złożyć w ciąu jednego miesiąca od doręczenia orzeczenia sądu okręgowego, chyba że ustawa stanowi inaczej. Niemniej w przypadku sprostowania termin ten zaczyna biec po doręczeniu postanowienia o sprostowaniu, jednak jedynie w takim zakresie, w jakim dokonano sprostowania orzeczenia (§ 443 ust. 1 zd. 2 s.s.p., podobnie w $\S 106$ ust. 2 s.ř.s.). Jak bowiem podkreśla się w orzecznictwie sądowym: „W odniesieniu do części, które nie były ani poprawione, ani zależne od sprostowania, strona była w stanie wnieść skargę kasacyjną od wydania pierwotnej decyzji. [...] w opinii Najwyższego Sądu Administracyjnego, wyjątek ten ma zastosowanie tylko wtedy, gdy skarga kasacyjna skierowana jest na orzeczenie skorygowane postanowieniem lub na orzeczenie uzależnione od sprostowania"81. W czeskim postępowaniu sądowoadministracyjnym, jeżeli sprostowanie dotyczy sentencji, wydaje się postanowienie, które może zawiesić wykonalność orzeczenia do czasu, gdy postanowienie naprawcze stanie się prawomocne („dokud opravné usnesení nenabude právní moci”). Co więcej, w takim przypadku dwutygodniowy termin do wniesienia skargi kasacyjnej (por. $§ 106$ ust. 2 s.řr.s.) biegnie od daty doręczenia wspomnianego postanowienia $^{82}$.

W polskim postępowaniu sądowoadministracyjnym wzmiankę o sprostowaniu sąd umieszcza na oryginale orzeczenia po uprawomocnieniu się postanowienia o sprostowaniu orzeczenia. Wzmiankę tę podpisuje kierownik sekretariatu. Po jej naniesieniu na oryginale orzeczenia należy dokonać aktualizacji odwzorowań cyfrowych akt prowadzonych w postaci tradycyjnej (papierowej) (§ 17 ust. 1 zarządzenia Prezesa NSA) ${ }^{83}$. Sprostowanie orzeczenia powinno być nadto odzwierciedlone w Centralnej Bazie Orzeczeń Sąów Administracyjnych przez dopisanie do sygnatury postanowienia o sprostowaniu. W przypadku żądania strony o zamieszczenie wzmianki o sprostowaniu należy ja także zamieścić na wypisach, które doręczono stronom. Dalsze wypisy muszą uwzględnić dokonane sprostowanie (art. $156 \S 2$ zd. 2 i 3 p.p.s.a.).

Jeżeli słowacki sąd administracyjny wyda postanowienie o sprostowaniu, dołącza się postanowienie do akt sądowych, a oryginał orzeczenia zawiera odniesienie do numeru pisma, pod którym postanowienie to jest dołaczone do $a t^{84}$. Podobna regulację $\mathrm{w}$ tym zakresie zawiera przepis rozporządzenia Ministra Sprawiedliwości w sprawie postępowania kancelaryjnego ${ }^{85} \mathrm{z} 11$ listopada 2005 r. zawarty w $§ 58$ ust. 5, stanowiący, że w przypadku dokonania

${ }^{81}$ Wyrok NSS z 21 lutego 2007 r., č. j. 4 Ans 3/2006-123, publ. pod nr 1177/2007 Sb. NSS.

82 Postanowienie NSS z 16 lutego 2011 r., č. j. 3 Ads 12/2011-79, <www.nssoud.cz>; zob. też Ziółkowska (2019): 371.

${ }^{83}$ Zarządzenie nr 14 Prezesa NSA z 6 sierpnia 2015 r. w sprawie ustalenia zasad biurowości w sądach administracyjnych.

${ }^{84}$ Baricová, Duditš (2018): 732.

${ }^{85}$ Rozporządzenie nr 543/2005 ze zm.Vyhláška Ministerstva spravodlivosti Slovenskej republiky o Spravovacom a kancelárskom poriadku pre okresne súdy, krajské súdy, Špeciálny súd a vojenské súdy, ze zmianami obowiązującymi od 1 stycznia 2020 r. 407/2019, wydane na podstawie $\S 86$ ust. $3, \S 117$ ust. 2 , 1118 ust. 2 a $§ 487$ ustawy nr 162/2015 Správny súdny poriadok. 
czynności sprostowania postanowienie w tej materii dołącza się do akt sprawy sądowej ze wskazaniem numeru.

W świetle $§ 113$ czeskiego regulaminu czynności NSS ${ }^{86}$, jeżeli kancelaria sądu (Soudní kancelář) stwierdzi uchybienia w wyroku, zwróci je w celu dokonania sprostowania. Jeżeli sprostowania dokonuje się bez wydania postanowienia, po tym gdy wyrok został doręczony stronom, przewodniczacy izby dokonuje bezpośrednio w wyroku nadpisania: „Dokonano korekty” (,Opravu provedl"), wskazując datę i pieczętując okrąłą pieczęcią urzędową (§ 115 ust. 4 k.s.NSS oraz por. $§ 163$ ust. 3 pkt b k.s.NSS).

\section{UWAGI KOŃCOWE}

Sprostowanie, stanowiące ważną instytucję proceduralna, która umożliwia stosunkowo prosty i odformalizowany sposób usunięcia oczywistych omyłek sądu w orzeczeniu - głównie natury technicznej, omyłek mimowolnych - zostało przewidziane i unormowane zarówno w polskiej, słowackiej, jak i czeskiej procedurze sądowoadministracyjnej. Regulacje prawne odnoszace się do tego trybu rektyfikacyjnego zostały zamieszczone w każdej z nich w rozdziale (części - s.řr.s.), który odnosi się do orzeczenia wydanego w postępowaniu sądowoadministracyjnym. Biorąc jednak pod uwagę zakres regulacji, należy podkreślić, iż regulacja polska jest bardziej kompleksowa niż słowacka czy czeska. W ustawie prawo o postępowaniu sądowoadministracyjnym w art. 156 uregulowano bowiem tryb sprostowania, rodzaje wad podlegajacych sprostowaniu (przesłanki), właściwość sądu, rodzaj posiedzenia, formę prawną sprostowania, a także dokonanie czynności związanych z dokonaniem sprostowania (skutki), także w odniesieniu do wyroku, który został utrwalony w systemie teleinformatycznym sądu. W art. 143 s.s.p. słowacki ustawodawca unormował termin, przesłanki sprostowania, formę prawną. Z kolei w czeskiej regulacji wskazano na podmiot dokonujacy sprostowania, przesłanki sprostowania, formę prawną oraz skutek jego wydania.

Zakres i większa lub mniejsza kompleksowość regulacji nie zmieniają faktu, że istota instytucji sprostowania w analizowanych reżimach prawnych jest taka sama - ma służyć usunięciu wadliwości nieistotnej orzeczenia. W żadnej z nich tryb ten nie może służyć naprawieniu wadliwości rozstrzygnięcia będącej pochodna wadliwego zastosowania norm prawa procesowego, materialnego czy ustrojowego. Ustawodawcy trzech analizowanych systemów prawnych podobnie określili granice przedmiotowe rozważanego trybu rektyfikacyjnego, wskazując w identyczny sposób na dwa rodzaje mankamentów, czyli na błędy pisarskie i rachunkowe. Jedyną różnicą w tym zakresie jest użyte sformułowanie odnoszące się do „innych oczywistych”: omyłek (w polskiej procedurze

86 Směrnice č.3/2017, Kancelářský a spisový řád Nejvyššího správního soudu (dalej jako: k.s.NSS) - Regulamin czynności NSS, wydany na podstawie $§ 29$ s.řs.s., ze zmianami obowiązującymi nr 3/2019. 
sądowoadministracyjnej) lub nieprawidłowości (w słowackim i czeskim postępowaniu sądowoadministracyjnym). W żadnej z procedur ustawodawcy nie wprowadzili legalnych definicji wad uzasadniajacych sprostowanie. Jednak powstała $\mathrm{w}$ ten sposób swoistego rodzaju luka uzupełniana jest przez bogate orzecznictwo sądowe w każdym z badanych systemów. Ustawodawcy zakresem analizowanego trybu rektyfikacyjnego w tożsamy sposób określili zakres sprostowania, którym może zostać objęta każda część orzeczenia (komparycja, sentencja, uzasadnienie).

W badanych systemach prawnych jednakowo uregulowano tryb uruchomienia rozważanego środka rektyfikacyjnego. Sprostowanie orzeczenia jest możliwe zarówno na zasadzie oficjalności (ex officio), jak i na wniosek. Niemniej $\mathrm{w}$ żadnej z nich nie zostało to wprost uregulowane. Wniosek taki jest możliwy pośrednio, przez interpretację § 143 s.s.p. oraz $§ 54$ ust. 4 s.ř.s. (nawet bez wniosku strony). Biorac jednak pod uwage postulat formułowania procesowych norm prawnych w sposób jasny, nie tylko dla sądu, lecz także dla stron, należy podnieść de lege ferenda potrzebę dokonania stosowanych zmian w tym zakresie. Jak się wydaje, potrzeba ta jest tym większa w procedurze krajowej, że literalna wykładnia przepisu art. 156 ust. 1 p.p.s.a. może mylnie sugerować, iż sprostowanie jest możliwe jedynie z inicjatywy sądu.

Zastosowanie instytucji sprostowania nie zostało uzależnione od terminu, stąd należy przyjąć, że jest możliwe w każdym czasie, o czym jednak expressis verbis przesądza jedynie regulacja słowacka. Zasadne wydaje się zatem zgłoszenie wniosku de lege ferenda adresowanego do ustawodawcy krajowego oraz czeskiego dotyczącego rozważenia uzupełnienia obowiązującej regulacji, w taki sposób, aby zwłaszcza strona postępowania nie miała wątpliwości, że instytucja ta jest możliwa do zastosowania także po uprawomocnieniu się orzeczenia.

W procedurze polskiej oraz słowackiej sprostowanie dokonywane jest $\mathrm{w}$ formie postanowienia. W regulacji czeskiej wdanie postanowienia $\mathrm{w}$ sprawie sprostowania jest uzależnione od umiejscowienia wady w orzeczeniu. Mianowicie uzasadnieniem jego wydania sa mankamenty sentencji. Co istotne, wszystkie analizowane porządki prawne przewidują formę postanowienia w przypadku odmowy uwzględnienia wniosku strony o sprostowanie. Na postanowienia naprawcze wydane na skutek sprostowania orzeczenia oraz odmawiające sprostowania przysługuje środek prawny (w p.p.s.a - zażalenie lub sprzeciw jako zwykłe środki, w s.s.p. - skarga kasacyjna, która w słowackim postępowaniu sądowoadministracyjnym ma charakter środka nadzwyczajnego (mimoriadneho opravného prostriedku), w s.ř.s. - skarga kasacyjna, która również traktowana jest jako nadzwyczajny środek prawny (oprauný prostředek mimořádný). Pomijając jednak charakter środka prawnego, w jaki ustawodawcy wyposażyli stronę, ważne jest, że pozwala on na zbadanie poprawności zastosowania albo odmowy trybu sprostowania.

Skutki zastosowania tego środka rektyfikacyjnego w regulacjach słowackiej i czeskiej różnią się od tych, które są właściwe dla polskiego porządku prawnego. Podczas gdy w świetle regulacji zawartej w p.p.s.a. wniosek o sprostowanie orzeczenia nie ma wpływu na bieg terminu do wniesienia środka 
zaskarżenia, z treści w $§ 443$ ust. 1 zd. 2 s.s.p. oraz $§ 106$ ust. 2 s.ř.s. wynika, że w przypadku sprostowania termin do wniesienia skargi kasacyjnej zaczyna biec po doręczeniu postanowienia o sprostowaniu, jednak jedynie w takim zakresie, w jakim dokonano sprostowania orzeczenia. Dodatkowo ustawodawca czeski dopuszcza zawieszenie wykonalności orzeczenia do czasu, gdy postanowienie naprawcze stanie się prawomocne. Wskazane rozwiązania niewątpliwie wydłużają procedowanie, a ich inkorporowanie do rodzimej ustawy (w której obecnie sprostowanie ma charakter deklaratoryjny) wymagałoby rozważenia chociażby potrzeby zachowania balansu między prawami strony a szybkościa postępowania.

Należy też zasygnalizować, że czynności techniczne związane ze sprostowaniem orzeczenia, w każdej z analizowanych procedur, zostały uregulowane w aktach wykonawczych do ustaw procesowych, co należy ocenić jako słuszne i właściwe, gdyż jest wyrazem dbałości o ograniczenie nadmiernego rozbudowywania aktów normatywnych przez wprowadzenie przepisów mających walor techniczny.

W refleksji końcowej należy zauważyć (i jednocześnie złożyć wniosek de lege ferenda), że w żadnym z analizowanych systemów prawnych ustawodawcy nie zdecydowali się na przyjęcie regulacji dotyczącej wniosku o sprostowanie wyroku złożonego dla zwłoki, który mógłby sprzyjać urzeczywistnieniu zasady zakazu nadużycia prawa procesowego przez strony ${ }^{87}$. W tym zakresie możliwe byłoby wykorzystanie (w całości lub w części) uregulowań zawartych w polskim postępowaniu cywilnym, w którym wniosek o sprostowanie wyroku złożony jedynie dla zwłoki w postępowaniu jest niedopuszczalny. Ustawowego określenia wymagałoby wskazanie, kiedy wniosek może zostać uznany za majacy charakter złożonego dla zwłoki, jak i określenie czynności sądu podjętych na skutek ich stwierdzenia (w szczególności pozostawienie wniosku i pism związanych z jego złożeniem w aktach sprawy oraz zawiadomienie strony wnoszącej o tym skutku tylko raz - przy złożeniu pierwszego pisma). Niezbędne wydaje się przy tym ustawowe „zwrócenie uwagi” na problem nadużycia praw procesowych przez stronę w odrębnym przepisie. Podkreślenia wymaga przy tym, że stosowanie tego rozwiązania w praktyce sądowej wymagałoby jednak rozwagi, gdyż ,złożenie przez stronę nawet kilku wniosków, ale o odmienne rodzajowo rozstrzygnięcia (np. najpierw o wykładnię, a następnie o sprostowanie), nie musi świadczyć a limine o grze strony na zwłokę" ${ }^{88}$, a każda sytuacja wymaga indywidualnego rozważenia przez sąd. Ustawodawcy, rozważając przyjęcie w analizowanych postępowaniach sądowoadministracyjnych rozwiązań (takich samych lub podobnych) wzorowanych na polskim postępowaniu cywilnym (co nie stanowiłoby precedensu, gdyż i bez tego czę-

${ }^{87}$ Regulacja taka obowiązuje w polskim postępowaniu cywilnym, od 7 listopada 2019 r. obowiązuje dodany art. 350¹ (na mocy ustawy z 4 lipca 2019 r., Dz. U. 2019, poz. 1469) o zmianie ustawy - Kodeks postępowania cywilnego oraz niektórych innych ustaw). Szerzej zob. np. Stempniak (2019): 729-731; Grajdura (2019): 1153-1154.

88 Druk nr 3137 - Rządowy projekt ustawy o zmianie ustawy - Kodeks postępowania cywilnego oraz niektórych innych ustaw - uzasadnienie: $45<$ https://www.sejm.gov.pl/Sejm8.nsf/druk. $\mathrm{xsp}$ ?nr=3137>. 
sto czerpią z rozwiązań procedury cywilnej), powinni je dopasować do specyfiki procedury sądowoadministracyjnej. Argumentem przemawiajacym za wprowadzeniem stosownych regulacji jest to, że sprzyjałaby ona zwiększeniu efektywności tych procedur przez ograniczenie nierzadkich przypadków nadużywania praw procesowych przez stronę wnoszacą o sprostowanie dla zwłoki w postępowaniu przed sądem administracyjnym. Rozwiązanie to wydaje się tym bardziej uzasadnione, jeżeli uznaje się czas za paradygmat w postępowaniu sądowoadministracyjnym.

Konkludując, pomimo wskazanych podobieństw i różnic oraz dostrzeganych braków $\mathrm{w}$ regulacji instytucji sprostowania jej ratio legis w każdym z trzech analizowanych systemów prawnych jest taka sama, czyli wyeliminowanie wadliwości nieistotnej orzeczenia, co leży zarówno w interesie wymiaru sprawiedliwości, który odpowiada za treść orzeczenia (zwłaszcza w obliczu tego, że wyrok stanowi dokument urzędowy), jak i strony postępowania, do której jest ono adresowane i ma zostać przez nią wykonane. Zasygnalizowane postulaty de lege ferenda moga prowadzić do większej przejrzystości regulacji prawnej sprostowania w warstwie normatywnej, a ostatni ze zgłoszonych - zabezpieczeniu sądu przed działaniami paraliżującymi procedowanie.

Agnieszka Ziótkowska Uniwersytet Ślaski w Katowicach agnieszka.ziolkowska@us.edu.pl https://orcid.org/0000-0002-9933-2667

Adamiak, B. (1988). Rektyfikacja decyzji w postępowaniu administracyjnym. Acta Universitatis Wratislaviennsis 922. Prawo 153. Wrocław: 7-13.

Baricová, J., Duditš, L. (2018). Oprava a doplnenie rozsudku, [w:] J. Baricová, M. Fečik, M. Števček, A.Filová et al., Správny súdny poriadok - komentár. Bratislava: 730-734.

Dauter, B. (2018). Art. 156 [Sprostowanie z urzędu], [w:] B. Dauter, A. Kabat, M. Niezgódka-Medek, Prawo o postępowaniu przed sądami administracyjnymi. Komentarz. Warszawa: $511-512$.

Drápal, L., Bureš, J. et al. (2009). Občanský soudní řád I. § 1 do 200. Komentář. Praha.

Gapska, E. (2009). Wady orzeczeń sądowych w postępowaniu cywilnym. Warszawa.

Grajdura, W. (2019). Regulacja prawna orzeczeń sądowych w świetle nowelizacji KPC dokonanej ustawą z 4.7.2019 r. Monitor Prawniczy 21: 1147-1156.

Hanzelová, I., Šingliarová, I. (2016). Správny súdny poriadok - komentár. Wolters Kluwer.

Jagielska, M., Jagielski, J., Stankiewicz, R., Grzywacz, M. (2019). Orzeczenia sądowe, [w:] R. Hauser, M. Wierzbowski (red.), Prawo o postępowaniu przed sądami administracyjnymi. Warszawa: 722-823.

Jakubecki, A. (2011). Sprostowanie, uzupełnienie i wykładnia wyroków, [w:] H. Dolecki, T. Wiśniewski (red.), Kodeks postępowania cywilnego. Komentarz. Tom 1. Warszawa: $1095-1104$.

Kocourek, T. (2019) [w:] Z. Kühn, T. Kocourek et al., Soudní řád správní. Komentář. Praha: 455-456.

Kunicki, I. (2010). Związanie sądu wydanym orzeczeniem w procesie cywilnym. Warszawa.

Litauer, J.J. (1933). Rektyfikacja wyroków w polskiej procedurze cywilnej. Ruch Prawniczy, Ekonomiczny i Socjologiczny 13(1): $1^{*}-13^{*}$.

Lubiński, K. (2016). Rektyfikacja wyroków w procesie cywilnym, [w:] T. Wiśniewski (red.), Postępowanie procesowe przed sądem pierwszej instancji. Warszawa: 779-878.

Piasecki, K. (1987). Sprostowanie wyroku, [w:] Z. Resich (red.), System prawa procesowego cywilnego. Tom 2. Warszawa: 365-378. 
Piasecki, K. (1961). Sprostowanie, uzupełnienie i wykładnia orzeczeń sądów cywilnych. Palestra 9: 9-11.

Piątek, W. (2017). Rodzaje orzeczeń sądu administracyjnego, [w:] W. Piątek (red.), Wykonanie wyroku sądu administracyjnego. Warszawa: 44-52.

Potěšil L., Šimiček V. et al. (2014). Soudní řád správní: komentář. Praha.

Rosengarten, F. (1971). Sprostowanie, uzupełnienie i wykładnia orzeczeń w postępowaniu cywilnym. Nowe Prawo 6: 872-881.

Sondel, J. (1997). Słownik łacińsko-polski dla prawników i historyków. Kraków.

Stempniak, A. (2019). Sprostowanie, uzupełnienie i wykładnia wyroków, [w:] A. Marciniak (red.), Kodeks postępowania cywilnego. Tom 2. Warszawa: 706-773.

Szustakiewicz, P. (2016). Sprostowanie z urzędu, [w:] A. Skoczylas, P. Szustakiewicz (red.), Prawo o postępowaniu przed sądami administracyjnymi. Warszawa: 278.

Szymanowski, M. (2018). Granice sprostowania orzeczenia w postępowaniu cywilnym, skutki ich przekroczenia, próba nowego spojrzenia. Radca Prawny 3: 79-100.

Tarno, J.P. (2010). Prawo o postępowaniu przed sądami administracyjnymi. Komentarz. Warszawa.

Woś, T. (2015) [w:] T. Woś (red.), Postępowanie sądowoadministracyjne. Warszawa: 307.

Woś, T., Knysiak-Molczyk, H., Romańska, M. (2016). Prawo o postępowaniu przed sądami administracyjnymi. Komentarz. Warszawa.

Zadrożniak, H.E. (2008). Rektyfikacja orzeczeń w postępowaniu cywilnym. Monitor Prawniczy 21: $1139-1146$.

Ziółkowska, A. (2019). Postępowanie międzyinstancyjne w postępowaniu sądowoadministracyjnym. Katowice.

\title{
JUDGMENT RECTIFICATION IN POLISH, SLOVAK, AND CZECH ADMINISTRATIVE COURT PROCEDURE
}

\author{
Summary
}

Judgments (rulings and decisions) issued in administrative court procedures can be affected by minor defects which, while not impacting their legal existence, must nevertheless be remedied. If a judgment contains inaccuracies, clerical and accounting errors, or other obvious mistakes, a corrective measure in the form of a rectification is applied (ex officio or upon application). This procedural institution exists in the Polish administrative court procedure (Article $156 \S 1$ p.p.s.a.) as well as in the Slovak (§ 143 sentence 1 s.s.p.) and the Czech (§ 54(4) sentence 1 s.r.s.s.) procedures. Despite the differences, which predominantly concern the effect of the application of this measure, in each of the procedures discussed herein, rectification consists in an exception from the self-binding effect and serves to eliminate the minor defects of a judgment, which is in the interests of both the judiciary and parties to proceedings.

Keywords: judgment rectification; minor defects in judgments 
